\title{
Identification and genetic diversity of two invasive Pissodes spp. Germar (Coleoptera: Curculionidae) in their introduced range in the southern hemisphere
}

\author{
Mesfin Wondafrash ${ }^{1,2}$, Bernard Slippers ${ }^{3}$, Jeff Garnas ${ }^{1}$, Géraldine Roux ${ }^{4}$, Jiri Foit ${ }^{5}$, David W. \\ Langor $^{6}$, Brett P. Hurley ${ }^{1}$ \\ ${ }^{1}$ Department of Zoology and Entomology, Forestry and Agricultural Biotechnology Institute (FABI), University of Pretoria, \\ Pretoria, 0002, South Africa \\ ${ }^{2}$ School of Plant Sciences, Haramaya University, Dire Dawa, P.O.Box 38, Ethiopia
}

${ }^{3}$ Department of Genetics, Forestry and Agricultural Biotechnology Institute (FABI), University of Pretoria, Pretoria, 0002, South Africa

${ }^{4}$ INRA UR633 Zoologie Forestière F-45075 Orléans \& Université d'Orléans, France.

${ }^{5}$ Department of Forest Protection and Wildlife Management, Faculty of Forestry and Wood Technology, Mendel University of Agriculture and Forestry, Zemedelska 3, 61300 Brno, Czech Republic

${ }^{6}$ Natural Resources Canada, Canadian Forest Service, Edmonton, 5320 - 122 Street NW, AB, T6H 3S5, Canada

Corresponding author

E-mail address: mesfinwondafrash@gmail.com or Mesfin.Gossa@ fabi.up.ac.za

Telephone: +27 (12)420-3938 or 3939

Fax: +27 (12) 420-3960

\section{Acknowledgements}

We thank members of Tree Protection Co-operative Program (TPCP), DST-National Research Foundation (NRF) and the University of Pretoria, South Africa for financial support. Kevin Dodds (US Forest Service, USA), Maria Lombardero (University of Santiago de Compostela, Spain), Rodrigo Ahumada (Bioforest SA, Concepción, Chile), Marcos Beeche (SAG, Chile), Cecilia Ruiz (Argentina) and Laura Amaral (Tacuarembó Department, Uruguay) are acknowledged for providing dead insect specimens. We also thank the two anonymous reviewers for their constructive suggestions and comments.

\begin{abstract}
During the first half of the twentieth century, two accidental cases of introduction of Pissodes weevils were recorded from the southern hemisphere. The weevils in South Africa were identified as the deodar weevil (Pissodes nemorensis) and those in South America as the small banded pine weevil (Pissodes castaneus). Wide distribution of the two species in their invasive range, general difficulty in identifying some Pissodes spp., and the varying feeding and breeding behaviours of the species in South Africa has necessitated better evidence of
\end{abstract}


species identity and genetic diversity of both species and population structure of the species in South Africa. Barcoding and the Jerry-to-Pat region of the COI gene were investigated. Morphometric data of the South African species was analysed. Our results confirmed the introduction of only one Pissodes species of North American origin to South Africa. However, this species is not $P$. nemorensis, but an unrecognized species of the P. strobi complex or a hybrid between P. strobi and P. nemorensis. Only P. castaneus, of European origin, was identified from South America. We identified ten mitochondrial DNA haplotypes from South Africa with evidence of moderate genetic structure among geographic populations. Terminal leader and bole-feeding weevils did not differ at the COI locus. A single haplotype was identified from populations of P. castaneus in South America. Results of the present study will have implications on quarantine, research and management of these insect species.

Keywords: bark weevils, invasive forest insects, Pissodes castaneus, Pissodes nemorensis, genetic diversity, population structure

\section{Introduction}

Insects are among the most dominant agents of biological invasions worldwide (Keller et al., 2011; McCullough et al., 2006). Forest ecosystems are increasingly threatened by invasive insect pests whose spread has been dramatically increased through the movement of wood products and packaging materials, as well as live plant material (Aukema et al., 2011; Tobin, 2015). It has also been shown that multiple introductions frequently increase genetic diversity of many introduced insects, including forest pests (Cognato et al., 2015; Garnas et al., 2016; Nadel et al., 2010). In addition, multiple introductions may allow unintended introductions of different lineages of the same species or cryptic species, as has been shown for the woodwasp, Sirex noctilio (Boissin et al., 2012), and the eucalyptus leaf weevil, Gonipterus spp. (Mapondera et al., 2012). Inabilities to recognize cryptic species and lack of knowledge of genetic diversity and population structure of invasive pests may lead to the use of uniform management approaches across populations of varying genetic background, which may potentially decrease the efficacy of management strategies. It can also have serious implications for the management of future spread, including quarantine (Garnas et al., 2012). Accurate identification of invasive insect pests and characterization of the genetic diversity and population structure are therefore key steps towards the development of successful management programs.

Members of the genus Pissodes Germar pose significant threats to their conifer hosts directly through feeding damage (Alfaro et al., 1994) and indirectly via their involvement in the transmission of forest pathogenic fungi (Jankowiak \& Bilański, 2013). All members of this genus are native to the northern hemisphere (Zhang, 2007), with species such as Pissodes strobi (Peck), P. terminalis Hopping, P. piniphilus (Herbst), $P$. yunnanensis Langor and Zhang, $P$. punctatus Langor and Zhang, P. nitidus Roelofs, $P$. nemorensis Germar and P. castaneus (De Geer) causing significant economic loss (Alfaro \& Ying, 1990; Craighead, 1950). The small banded pine weevil, $P$. castaneus, and the deodar weevil, $P$. nemorensis, were accidentally introduced outside their native ranges. The former has invaded South America (Uruguay, Argentina, Brazil and Chile) 
(Abgrall et al., 1999; Anon, 1970; CABI, 2014; Pereyra et al., 2015b; Zaleski et al., 2013), while the later was reported to have spread to South Africa, Russia and Japan (EPPO, 1999; Zhang, 2007). These invasive species have now become pests of Pinus in non-native plantations in their introduced ranges in the southern hemisphere.

Pissodes nemorensis was first reported in South Africa in 1942 on Pinus radiata (EPPO, 1999; Webb, 1974; Zhang, 2007). Pissodes nemorensis belongs to the P. strobi complex (Boyce et al., 1994). Adults within this species complex are difficult to distinguish in part due to intraspecific variation in life history and morphology which confounds the designation of discrete characters uniquely and/or universally present to differentiate species (Phillips et al., 1987), due to variable host preference in different parts of their range (Smith \& Sugden, 1969), and due to the fact that there is hybridization amongst some species (Boyce et al., 1994; Langor \& Sperling, 1997; Langor, unpublished data). This confusion raises the possibility of misidentification of Pissodes spp. in South Africa and around the globe as well as possible undetected invasion of multiple cryptic species. As the identity of the Pissodes in South Africa is in question, we use Pissodes sp. in the manuscript. This weevil is now present throughout the major Pinus growing provinces of the country, infesting all major commercially grown Pinus species (authors' observation). The widespread distribution of Pissodes sp. in South Africa might be the result of the extensive movement of wood material within the country, in addition to natural spread via flight. Given how long the weevil has been known in the country, it is possible that multiple introductions have occurred, as has been observed in a number of other invasive insects in South Africa and elsewhere (Garnas et al., 2016).

In the Western Cape province of South Africa, Pissodes sp. has been observed feeding and breeding on previous year's terminal leaders of healthy Pinus trees and on the main trunks of dying or recently dead trees (M. Wondafrash, personal observation). Dieback of the terminal leader and the subsequent forking of the bole is relatively common in the provinces of Mpumalanga and KwaZulu-Natal, though the causal factors appear to be primarily abiotic; feeding and larval development within terminal shoots has only very rarely been observed outside of P. radiata in the Cape (J. Garnas, personal observation). The feeding and breeding behaviour on growing leaders is similar to that observed for P. strobi and P. terminalis (Langor \& Sperling, 1995), while the feeding and breeding behaviour in the main trunk is similar to that of $P$. nemorensis and $P$. schwarzi in their native range (Atkinson et al., 1988; Fontaine et al., 1983; Langor \& Sperling, 1997). However, in its native range, $P$. nemorensis is also known to sometimes infest the terminal leaders of healthy trees (Overgaard \& Nachod, 1971; Phillips et al., 1984), thus making it difficult to distinguish damage caused by P. terminalis and P. strobi. Furthermore, hybrids of these two species have been detected in terminal leaders of Pinus (Boyce et al., 1994; Langor \& Sperling, 1997). No published accounts are available that examine whether the observed variation and spatial partitioning of feeding and breeding behaviour in South Africa are the result of interactions with different hosts, environmental factors, or if they could arise from unique behaviour of distinct populations or cryptic species.

Pissodes castaneus was first recorded in South America in Uruguay in about 1919 and was subsequently recorded in Argentina, Brazil and Chile (Steve \& Shaw, 1958; Zaleski et al., 2013). The weevil often prefers young, stressed Pinus trees (Gomez \& Hartel, 2010; Iede et al., 2007). In its native range, the weevil almost exclusively prefers 2-15 year old Pinus trees and results in significant economic losses in 
regenerating stands (CABI, 2014; Day et al., 2004; Panzavolta \& Tiberi, 2010). In its invasive range in South America, $P$. castaneus causes significant damage in pine nurseries, young trees growing on marginal soils and mature plantations stressed by biotic and abiotic factors (Gomez \& Hartel, 2010). It also attacks some species of Abies and Pseudotsuga in Uruguay (Panzavolta \& Tiberi, 2010).

The aim of this study is firstly to assess the species identity of the two invasive Pissodes species in the southern hemisphere (South Africa and South America). In addition, we investigate the genetic diversity and structure of populations of the Pissodes in South Africa, specifically with respect to geographic distribution and feeding and breeding behaviours (i.e., terminal leader versus bole feeding). Finally, we compare the genetic diversity of the two invasive species in their respective invasive ranges.

\section{Materials and methods}

\section{Specimen collection and preservation}

Weevils were collected from 27 sites across three major Pinus-growing provinces of South Africa: Western Cape, Mpumalanga and KwaZulu-Natal, from July to September 2013. Three Pinus plantations were randomly selected from each province, and in each plantation three sites with active Pissodes infestation were selected for study. Insects were then collected from five randomly selected Pissodes infested trees per site, for a total of 135 trees (Online Resource 1). All specimens from Western Cape were collected from P. radiata and those from Mpumalanga and KwaZulu-Natal were from $P$. patula. Most of the collections were obtained from recently dead trees, though some collections were obtained from living trees in the Western Cape. A total of 675 insects (i.e five per tree and twenty five per site) were preserved in absolute ethanol and kept frozen at $-20{ }^{\circ} \mathrm{C}$ until DNA extraction. Preserved (70\% EtOH) Pissodes specimens were obtained from South America (Chile, Uruguay and Argentina), Europe (Spain and Czech Republic) and North America (USA) (Online Resource 2). As part of our effort to determine the identity of the Pissodes sp. in South Africa, we also obtained identified and frozen specimens of $P$. nemorensis from the USA (New York and Florida) and Canada (Ontario) (Online Resource 2).

\section{DNA extraction and cleaning}

Prior to DNA extraction, the preserved insect specimens were rinsed with sterilized distilled water and the whole insect body was ground with Retsch MM 301 Mixer Mill (Retsch GmbH, Rheinische, Germany) using metal beads. Total genomic DNA was extracted from 241 specimens (i.e. two insects per sampled tree) from South Africa (Online Resource 1) and from 34 specimens outside South Africa (Europe, North America and South America) (Online Resource 2) using a slightly modified phenol/chloroform extraction protocol (Goodwin et al., 1992). The genomic DNA was also cleaned following the phenol/chloroform DNA extraction protocol (Goodwin et al., 1992). The resulting DNA was suspended in $25 \mu 1$ of ultrapure (SABAX) water. Concentration and quality of the DNA was determined by a NanoDrop 1000 Spectrophotometer (Thermo Fisher 
Scientific Inc., Wilmington, U.S.A.). The quality was further evaluated through electrophoresis on $1 \%$ agarose gel. All extracted DNA was stored at $-20{ }^{\circ} \mathrm{C}$.

\section{Amplification of mtDNA (COI)}

The Jerry-to-Pat region of the mitochondrial cytochrome c oxidase I (COI) gene was amplified from 241 specimens from South Africa using the universal primers C1-J-2183 (Jerry): 5'CAACATTTATTTTGATTTTTT-3' and TL2-N-3014 (Pat): 5'-TCCAATGCACTAATCTGCCATATTA-3' (Simon et al., 1994). The same gene region was amplified from specimens obtained from Europe, North America and South America. The COI barcoding region of all haplotypes from South Africa and the specimens from other countries was amplified using the primers LCO1490: 5'-GGTCAACAAATCATAAAGATATTGG3' and HC02198: 5'-TAAACTTCAGGGTGACCAAAAAATCA-3' (Simon et al., 1994).

Amplification reactions were performed in a $25 \mu \mathrm{L}$ reaction solution comprising $16.1 \mu \mathrm{L}$ of ultrapure (SABAX) water, $3 \mu \mathrm{L}$ of 10x concentrated PCR reaction buffer with $20 \mathrm{mM} \mathrm{MgCl}_{2}$ (Roche Diagnostics GmbH, Mannheim, Germany), $2.5 \mu \mathrm{L}$ of deoxynucleotide triphosphate (dNTP) mix (10 mM; $2.5 \mathrm{mM}$ each), $1 \mu \mathrm{L}$ of each primer $(10 \mu \mathrm{M})$ (WhiteSci), $0.4 \mu \mathrm{L}$ of FastStart Taq DNA polymerase $\left(5 \mathrm{U}^{-1} \mathrm{~L}^{-1}\right.$ ) (Roche Diagnostics $\mathrm{GmbH}$, Mannheim, Germany) and $1 \mu \mathrm{L}$ of cleaned insect genomic DNA (100ng $\left.\mu \mathrm{L}^{-1}\right)$. The reactions were run in a Bio-Rad iCycler thermocycler (BIO-RAD, Hercules, CA, USA) at $95{ }^{\circ} \mathrm{C}$ for $3 \mathrm{~min}$, followed by 35 cycles at $95{ }^{\circ} \mathrm{C}$ for $1 \mathrm{~min}, 51{ }^{\circ} \mathrm{C}$ for $1 \mathrm{~min}$ and $72{ }^{\circ} \mathrm{C}$ for $1.5 \mathrm{~min}$ and final extension at $72{ }^{\circ} \mathrm{C}$ for $8 \mathrm{~min}$. The amplification reactions and thermocycling conditions for both primer sets remained the same, except an annealing temperature of $42{ }^{\circ} \mathrm{C}$ was used for amplifying the barcoding region of $\mathrm{COI}$ instead of the $51{ }^{\circ} \mathrm{C}$ used for the $3^{\prime}$ end region of COI. Amplification of the target DNA fragments was checked by running electrophoresis of a mixture of $4 \mu \mathrm{L}$ of the PCR aliquots and $2 \mu \mathrm{L}$ of GelRed ${ }^{\mathrm{TM}}$ (Biotium, USA) along with 100bp DNA molecular weight marker (Thermo Scientific O'Gene Ruler ${ }^{\mathrm{TM}}$ ) on $2 \%$ agarose gel. Following this, the fragments were visualized under UV light and gel images were captured using Gel Doc ${ }^{\mathrm{TM}}$ EZ Imager (BIO-RAD).

\section{Cleaning PCR products and sequencing PCR}

The PCR products were cleaned by adding $8 \mu \mathrm{L}$ of ExoSAP-IT (USB Corporation, Cleveland, OH) and incubating the mixture at $37{ }^{\circ} \mathrm{C}$ and $80{ }^{\circ} \mathrm{C} ; 15 \mathrm{~min}$ at each temperature point. The forward and reverse sequencing reactions were performed in a $12 \mu \mathrm{L}$ reaction volume made of $6.4 \mu \mathrm{L}$ of ultrapure (SABAX) water, $2.1 \mu \mathrm{L}$ of sequencing buffer, $0.5 \mu \mathrm{L}$ of BigDye ${ }^{\mathrm{TM}}$ Ready Reaction Mixture with Amplitaq DNA polymerase (Perkin-Elmer Applied Biosystems, Warrington, UK), $1 \mu \mathrm{L}$ of either of the primers $(10 \mu \mathrm{M})$ and $2 \mu \mathrm{L}$ of purified PCR product (50 ng $\mu \mathrm{L}^{-1}$ ). The mixture was then incubated in a Bio-Rad iCycler thermocycler (BIO-RAD) for 35 cycles at $96{ }^{\circ} \mathrm{C}$ for $10 \mathrm{~s}, 51{ }^{\circ} \mathrm{C}$ for $5 \mathrm{~s}$ and $60{ }^{\circ} \mathrm{C}$ for $4 \mathrm{~min}$. The sequencing products were cleaned and run and visualized on ABI PRISM ${ }^{\mathrm{TM}} 3500$ automatic DNA Analyzer (Applied BioSystems, USA).

For some European and North American species (P. strobi, P. terminalis, P. nemorensis, P. schwarzi, $P$. validirostris, $P$. pini, $P$. piniphilus, $P$. punctatus and $P$. harcyniae), sequences of the barcoding and Jerry-toPat region of the COI gene were downloaded from the GenBank and the BOLD System 
(http://www.boldsystems.org/). Jerry-to-Pat region sequences of three P. castaneus specimens from France, Italy and Slovenia (one from each) were included in our analyses.

\section{Sequence edition and alignment}

The raw sequence data were edited using CLC Main Workbench 6.0 (CLC Bio, Denmark) and Biological Sequence Alignment Editor (BioEdit) software (Hall, 1999) version 7.0.9. The edited sequences were aligned using an online Multiple Sequence Alignment Program (MAFFT) version 7 (http://mafft.cbrc.jp/alignment/software/) (Katoh \& Standley, 2013). The aligned sequences were further edited in BioEdit by comparing against sequencing trace files.

\section{Morphometric measurements}

Sixty-eight female and 72 male Pissodes specimens collected from nine sites across South Africa (Online Resource 1) were characterised by measuring 15 morphometric characters (Online Resource 5) used to discern members within the $P$. strobi complex (Williams \& Langor, 2002). The specimens were measured using calibrated AxioCam ICc 5 Zeiss camera attached to a Carl Zeiss Stemi 2000 stereo microscope.

\section{Data analysis}

Phylogenetic analysis

Separate phylogenetic analyses were conducted on the Jerry-to-Pat and the barcoding region of the COI gene as sequences for both loci was not available for many of the specimens in publicly available databases. The analysis on the barcoding region was conducted with the aim of including some Eurasian Pissodes spp. ( $P$. validirostris, P. pini, P. piniphilus and P. harcyniae) and P. strobi, whose specimens were missing in our collection, but their barcoding sequences were available in the Bold System. The analyses were done using sequences of Pissodes specimens from South Africa, USA, Canada, Argentina, Chile, Uruguay, Czech Republic, France, Italy, Slovenia, Spain and those from the GenBank and the BOLD System. GenBank sequences of $P$. affinis Randall and Curculio salicivorus Paykull were used as outgroups in phylogenetic analysis of the Jerry-to-Pat and barcoding region, respectively. Maximum Likelihood (ML) and Maximum Parsimony (MP) phylogenies were inferred separately for the Jerry-to-Pat and barcoding region of COI using PhyML version 3 (Guindon et al., 2010) and PAUP* 4.0 beta 10 (Swofford, 2000), respectively. Akaike information criterion in the program jModelTest 2.1.1 (Darriba et al., 2012) was used to determine the most appropriate nucleotide substitution model for each locus (TPM1uf+I+G for barcoding region and $\operatorname{TrN}+\mathrm{I}$ for Jerry-to-Pat region). The bootstrap method (1000 iterations) was used to estimate the degree of support for internal nodes of the MP trees (Felsenstein, 1985). The net sequence divergence between and within species was computed using the Kimura 2-parameter model in Molecular Evolutionary Genetics Analysis (MEGA) software (Tamura et al., 2011).

Analysis of genetic diversity and population structure was conducted only using sequences of the Jerryto-Pat region of COI gene. The number of segregating sites $(\mathrm{S})$, haplotype diversity $(\mathrm{Hd})$, the average number of nucleotide differences $(\mathrm{k})$ and nucleotide diversity $(\mathrm{Pi})$ were calculated for each of the nine populations using 
DNA Sequence Polymorphism (DnaSP) version 5.10.01 software (Librado \& Rozas, 2009). An haplotype network was constructed using Network (Bandelt et al., 1999).

Genetic structure analysis

Analysis of molecular variance (AMOVA) and Mantel correlation test were conducted in GenAlex 6.501 (Peakall \& Smouse, 2012) to examine the genetic structure of populations of Pissodes sp. across different Pinus growing provinces of South Africa. A separate AMOVA was done for the population in the Western Cape to investigate the genetic structure of the populations showing differential feeding and breeding behaviours (i.e., those in terminal leaders and those in boles). DNA Sequence Polymorphism (DnaSP) version 5.10.01 software (Librado \& Rozas, 2009) was used to estimate the fixation indices (Fst). Due to differences in the number of specimens sequenced in South Africa and South America, diversity comparisons were made by resampling sequences of specimens from South Africa.

\section{Morphometric data analysis}

Morphometric data measured in the present study and those reported by Williams and Langor (2002) were compared by factor analysis (FA) in order to describe morphometric similarity/difference of the South African Pissodes specimens to members of the P. strobi complex (P. strobi, P. terminalis, P. nemorensis and P. schwarzi) in North America. All the morphometric characters used by Williams and Langor (2002) except "width of elytra at anterior margin of declivity (EA)" and "depth of mesothorax at deepest point (MD)" were used in our FA (i.e., 13 measured and three calculated ratio characters in total). Prior to FA, original datasets for North American species were simulated based on the published mean, standard error and range values (assuming normal distributions). The FA produced a set of variables (factors) that were linear combinations of the original variables. The new variables (factors) were independent of each other and ranked according to the amount of variation. After the initial factor extraction by the principal component method, an orthogonal normalised varimax rotation was used to estimate the factor loadings. Only factors with an eigenvalue greater than one were extracted. These analyses were performed in Statistica 12.0 (StatSoft, 2013).

\section{Results}

\section{Identification of the Pissodes specimens introduced in South Africa}

A 578 bp segment of the Jerry-to-Pat region of the COI gene was successfully sequenced for 241 specimens. There were 13 polymorphic sites (2.25\% of the segment), resulting in 10 distinct haplotypes (Fig. 1) of an apparent single species. Consensus trees for both gene regions clearly showed that all representative haplotypes from South Africa grouped together in a strongly supported distinct clade (bootstrap value $\geq 95 \%$, branch length $\geq 0.85$; Figs. 2 and 3). For both COI regions, the South African clade was sister to GenBank sequences of $P$. strobi, also strongly supported as a distinct clade (bootstrap value $\geq 96 \%$, branch length $\geq 0.94$ ). Together P. strobi, P. nemorensis and the Pissodes sp. formed a well-supported clade, though P. nemorensis 
does not share the most recent common ancestor of the other two taxa. The Pissodes species from South Africa has the least sequence divergence from $P$. strobi populations $(0.031-0.035)$ compared to its divergence from other species, namely P. nemorensis (0.064 - 0.067), P. terminalis (0.070), P. schwarzi (0.082), P. castaneus (0.116 - 0.128), P. pini (0.119) and the outgroup P. affinis (0.159) (Online Resource 3). In general, the weevil in South Africa was more closely related to species native to North America than to those native to Europe. Similar results were obtained from phylogenetic and sequence divergence analyses based on sequences of the barcoding region of the COI gene (Online Resource 4).

Analysis of 13 morphometric measurements showed that both the females and males of the Pissodes sp. in South Africa grouped most closely to P. nemorensis and P. schwarzi than to P. strobi. More than $67 \%$ of the variance in the FA was explained by axis 1 (45.8\%) and 2 (22.7\%; Fig. 4). Measurements of all morphometric characters, except snout apex proportion (SA), were the highest in both females and males of the Pissodes sp. in South Africa (Online Resource 5) compared to published morphometries of other members of the P. strobi complex (Williams \& Langor, 2002). The depth of pronotum along posterior margin (PD) and length of snout between apex and eye margin at mid-height (SL) were found remarkably longer in both the females and males of the Pissodes sp. in South Africa (Online Resource 5) than other members of the P. strobi complex (Williams \& Langor, 2002).

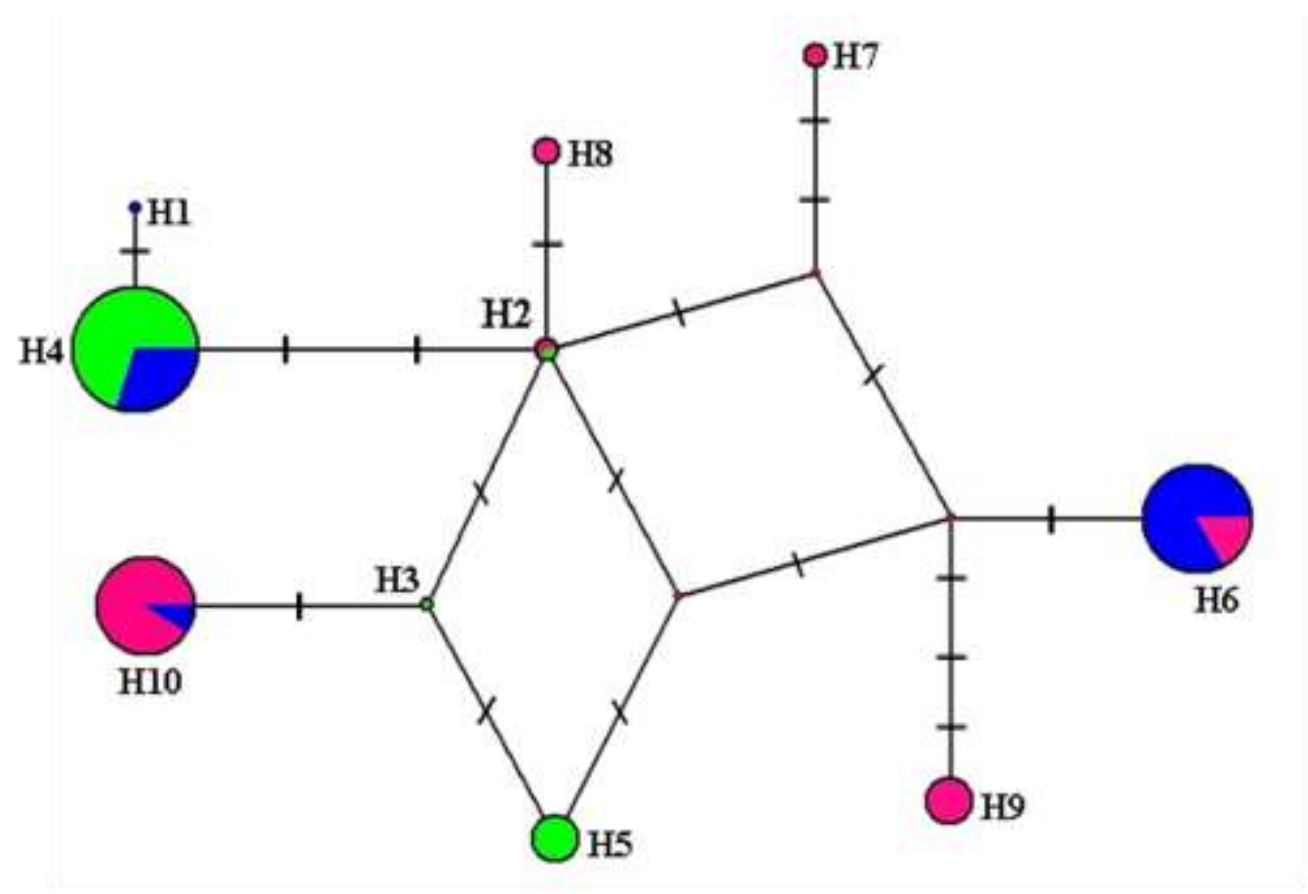

\section{Mpumalanga \\ Western Cape \\ KwaZulu-Natal}

Fig. 1 Median-joining haplotype network of Pissodes sp. in South Africa based on 578 bp segment of the Jerry-to- Pat region of the COI gene. The size of the circle is proportionate to the abundance of the haplotype and vice versa 


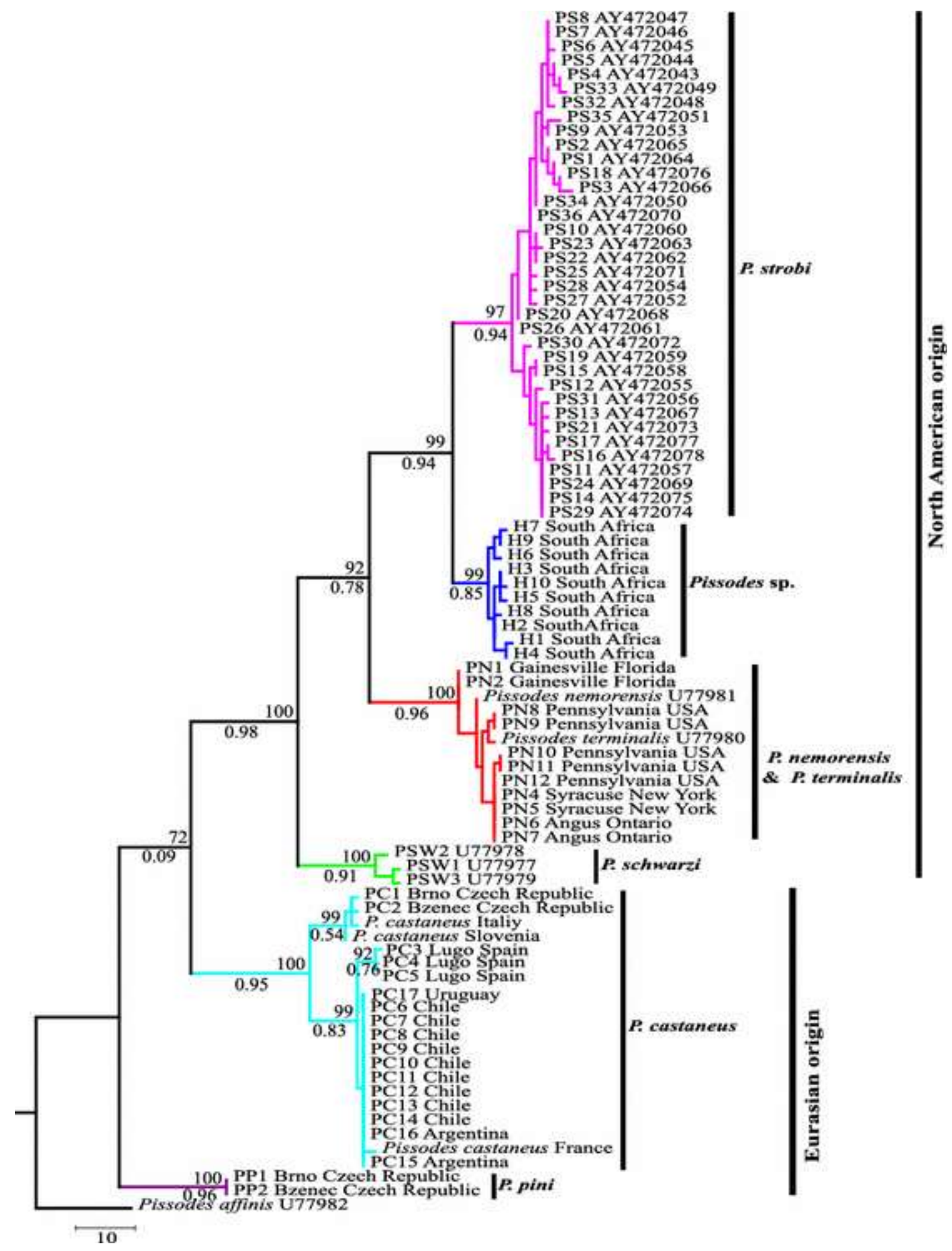

Fig. 2 Phylogenetic tree based on maximum parsimony and maximum likelihood analysis of a 578 bp segment of the Jerry-to-Pat region sequence of the COI gene. A sequence of $P$. affinis was used as an outgroup. GenBank accession numbers are indicated where available. The numbersabove and below branches indicate bootstrap value and branch length, respectively. Consistency index $(\mathrm{CI})=0.595$; retention index $(\mathrm{RI})=0.953$; homoplasmy index $(\mathrm{HI})=0.405$ 


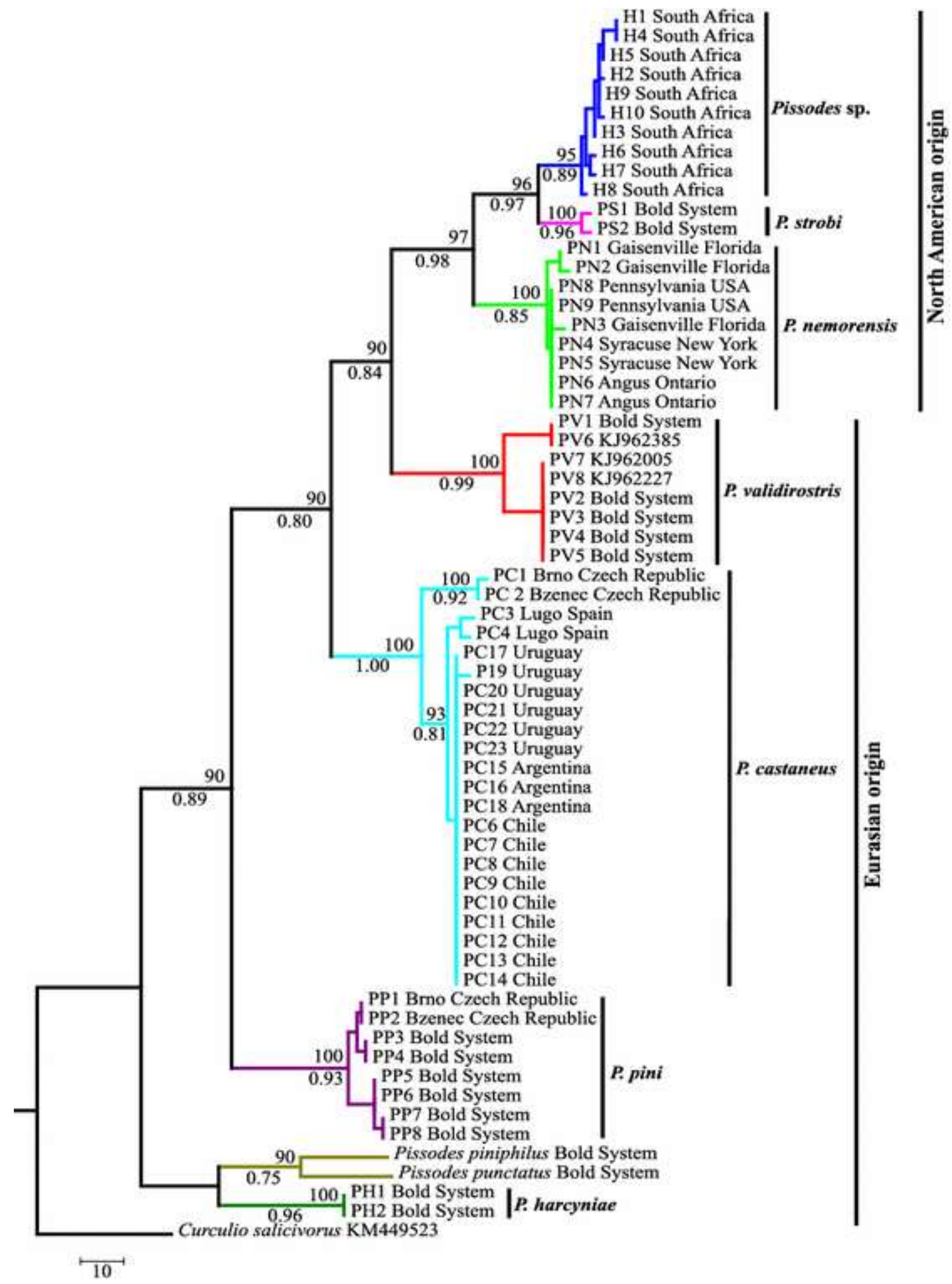

Fig. 3 Phylogenetic tree based on maximum parsimony and maximum likelihood analysis of a 582 bp sequence of the barcoding region of the COI gene for 8 species of Pissodes. A sequence of Curculiosalicivorus from GenBank was used as outgroup. GenBank accession numbers are indicated where available. The numbersabove and below branches indicate bootstrap value and branch length, respectively. Consistency index $(\mathrm{CI})=0.556$; retention index $(\mathrm{RI})=0.921$; homoplasmy index $(\mathrm{HI})=0.444$ 


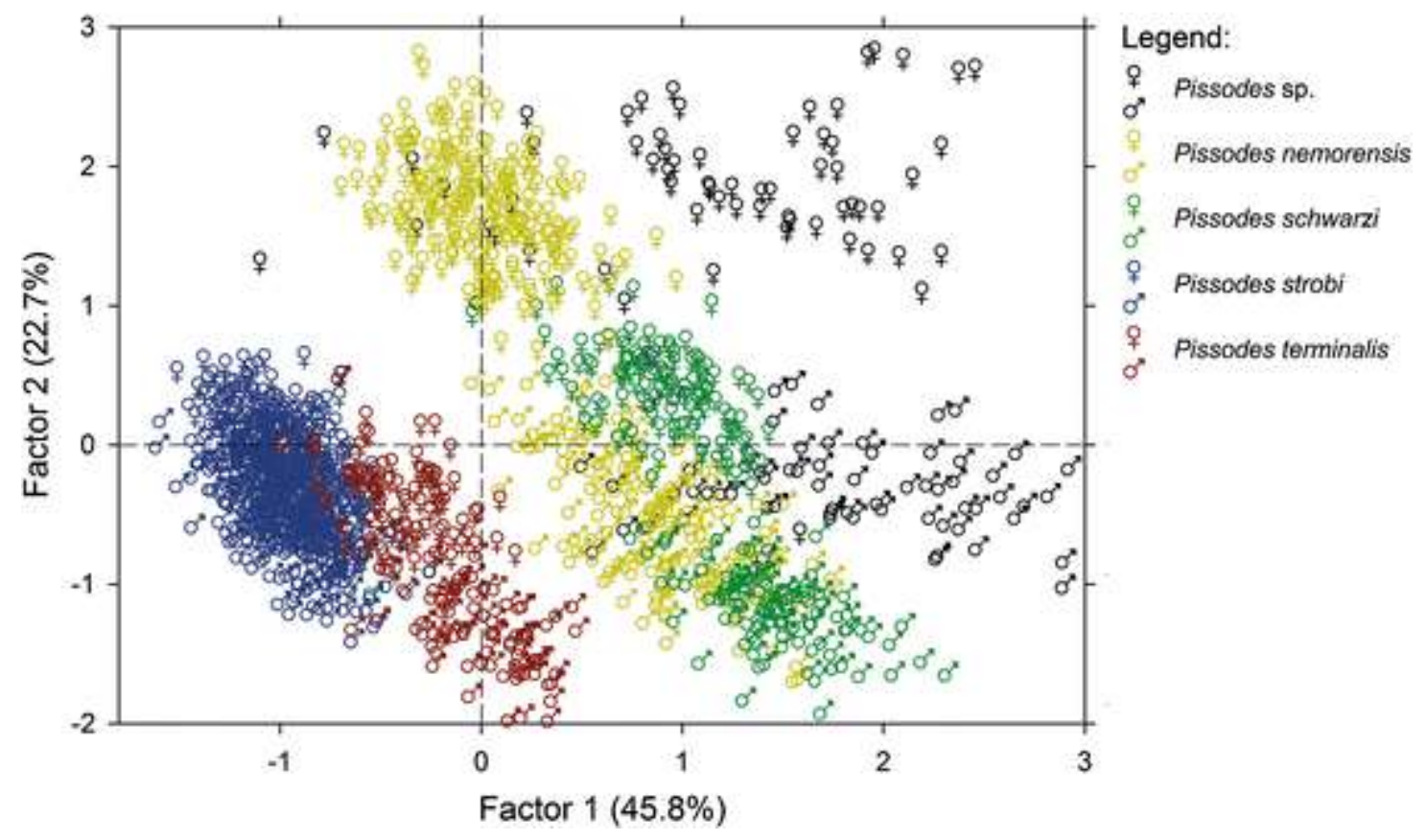

Fig. 4 Ordination plot based on factor analysis of female and male morphometric measurements of the Pissodes sp. in South Africa and members of the Pissodes strobi complex. Data for the four North American Pissodes spp. (P. strobi, P. terminalis, P. schwarzi and P. nemorensis) was obtained from Williams and Langor (2002)

\section{Identification of the Pissodes species introduced in South America}

In the present study, analysis of the barcoding region and the Jerry-to-Pat region of the COI gene grouped all specimens from South America (Argentina, Chile and Uruguay) and Spain and two specimens from the Czech Republic together with identified P. castaneus specimens from France, Italy and Slovenia, in a strongly supported clade (bootstrap value $=100$; branch length =1) (Fig. 2 and 3). The South American specimens grouped most closely with $P$. castaneus from France, compared to the specimens of the same species from Italy, Slovenia, Spain and Czech Republic. None of the specimens from South America grouped with the North American or the South African Pissodes species, suggesting its origin from Europe. The results supported the introduction of a single species, P. castaneus, in all three South American countries (Argentina, Chile and Uruguay).

\section{Genetic diversity of Pissodes species in South Africa and P. castaneus in South America}

Estimates of genetic diversity of the Pissodes species in South Africa was made based on sequences of the Jerry-to-Pat region of the COI gene (Table 1). The sequence divergence among the 10 haplotypes ranged from 0.2 to $1.4 \%$. An estimated overall nucleotide diversity ( $\mathrm{Pi}$ ) of $0.006(\mathrm{~S}=13, \mathrm{~h}=10, \mathrm{Hd}=0.750, \mathrm{~K}=3.365)$ was obtained from the entire population in South Africa, with the highest nucleotide diversity of $0.005(\mathrm{~S}=13, \mathrm{~h}=$ $6, \mathrm{Hd}=0.597, \mathrm{~K}=3.043)$ from KwaZulu-Natal and the lowest nucleotide diversity of $0.002(\mathrm{~S}=4, \mathrm{~h}=4, \mathrm{Hd}=$ $0.338, \mathrm{~K}=1.260$ ) from the Western Cape. At the population level, the lowest diversity detected for Pissodes in South Africa was in Ruigtevlei in the Western Cape and the highest from Underberg in KwaZulu-Natal (Table 1). In general, populations in the summer-rainfall regions of the country (where P. patula and other Pinus spp. 
grow) tend to be more diverse than the populations in the winter-rainfall areas where $P$. radiata is predominantly grown. Analyses made on $P$. castaneus specimens from South America indicated that populations in Argentina, Chile and Uruguay consisted of only a single haplotype.

Table 1 Genetic diversity parameters of Pissodes sp. in nine populations in three provinces (Western Cape, Mpumalanga, and KwaZuluNatal) of South Africa

\begin{tabular}{|c|c|c|c|c|c|c|c|}
\hline Province & Site & $\bar{n}$ & $\overline{\mathbf{S}}$ & $\mathbf{h}$ & Hd & $\mathbf{K}$ & $\mathbf{P i}$ \\
\hline \multirow{4}{*}{ Western Cape } & Braken Hill & 30 & 4 & 2 & 0.287 & 1.149 & 0.002 \\
\hline & Ruigtevlei & 30 & 4 & 3 & 0.246 & 0.903 & 0.002 \\
\hline & Bergplaas & 14 & 4 & 3 & 0.582 & 2.044 & 0.004 \\
\hline & Total & 78 & 4 & 4 & 0.338 & 1.260 & 0.002 \\
\hline \multirow{4}{*}{ Mpumalanga } & Helvetia & 28 & 5 & 2 & 0.423 & 2.116 & 0.004 \\
\hline & Torburnlea & 29 & 6 & 3 & 0.549 & 2.655 & 0.005 \\
\hline & Rooihoogte & 29 & 7 & 3 & 0.493 & 2.414 & 0.004 \\
\hline & Total & 86 & 8 & 4 & 0.509 & 2.50 & 0.004 \\
\hline \multirow{4}{*}{ KwaZulu-Natal } & Shafton & 26 & 9 & 5 & 0.625 & 3.428 & 0.006 \\
\hline & De Rust & 29 & 9 & 4 & 0.414 & 2.153 & 0.004 \\
\hline & Underberg & 26 & 10 & 6 & 0.738 & 3.474 & 0.006 \\
\hline & Total & 81 & 13 & 6 & 0.597 & 3.043 & 0.005 \\
\hline Entire population & Grand total & 241 & 13 & 10 & 0.750 & 3.365 & 0.006 \\
\hline \multicolumn{8}{|l|}{${ }^{\mathrm{n}}$ sample size } \\
\hline \multicolumn{8}{|c|}{${ }^{\mathrm{S}}$ number of segregating sites } \\
\hline \multicolumn{8}{|c|}{${ }^{\mathrm{h}}$ number of haplotypes } \\
\hline \multicolumn{8}{|c|}{${ }^{\mathrm{Hd}}$ haplotype diversity } \\
\hline \multicolumn{8}{|c|}{${ }^{\mathrm{K}}$ mean number of nucleotide differences } \\
\hline${ }^{\mathrm{Pi}}$ nucleotide divers & & & & & & & \\
\hline
\end{tabular}

\section{Genetic structure of the Pissodes species in South Africa}

Of the 10 haplotypes of Pissodes sp. in South Africa, H4, H6 and H10 were the most common, representing $84.6 \%$ of all samples. Each of these haplotypes along with $\mathrm{H} 2$ were shared between at least two populations (Fig. 1). The remaining six haplotypes were unique to a single province. The shared haplotypes indicate a lack of strong population genetic structure. Genetic structure analysis for P. castaneus in South America was not determined, since all of the populations contained a single haplotype across its invasive range.

Analysis of molecular variance (AMOVA) was performed for the three provinces (Western Cape, Mpumalanga and KwaZulu-Natal) and nine populations; populations being represented by plantations (Braken Hill, Ruigtevlei, Bergplaas, Helvetia, Torbunlea, Rooihoogte, Shafton, De Rust and Underberg) in South Africa. The total molecular variance was partitioned into three different sources (among provinces, between populations in a province and within populations). A moderate level of structure was recorded among provincial populations $(F s t=0.41$ and $\mathrm{Nm}=0.7)$. The highest proportion of the total molecular variance was explained by the variation within populations (57\%) followed by a $40 \%$ variation among provinces and $3 \%$ within populations in a province (Table 2). A Mantel correlation test resulted in a moderate level of correlation $(\mathrm{R}=0.22)$ between genetic and geographic distance (Fig. 5). 
Table 2 Hierarchical analysis of molecular variance (AMOVA) for nine geographically distinct populations of Pissodes sp. across three provinces (Western Cape, Mpumalanga and KwaZulu-Natal) in South Africa

\begin{tabular}{llllc}
\hline Source of variation & Df & SS & MS & Est. Var. \\
\hline Among provinces & 2 & 130.01 & 65.00 & $0.78^{* * *}$ \\
Among populations within a province & 6 & 14.86 & 2.48 & $0.05^{* *}$ \\
Within populations & 232 & 259.00 & 1.12 & $1.12^{* * *}$ \\
Overall Fst & & & $0.42^{*}$ \\
Overall Nm & & & 0.70 \\
\hline
\end{tabular}

${ }^{*}$ Significant at 0.05 level

${ }^{* * *}$ Significant at 0.01 level

${ }^{* * * *}$ Significant at 0.001 level

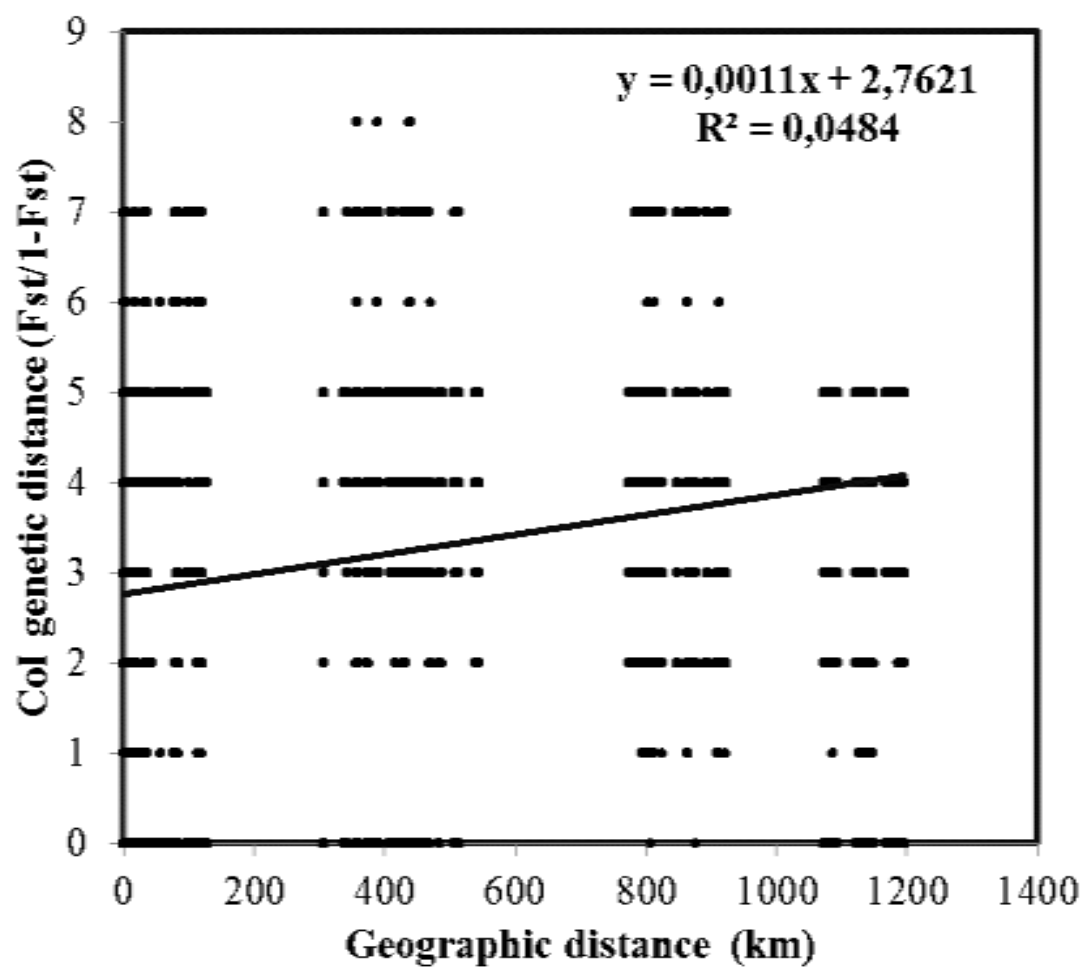

Fig. 5 Regression analysis of pairwise genetic distance versus pairwise geographic distance of populations of the Pissodes sp. in South Africa (Mantel $\mathrm{R}=0.220, \mathrm{P}=0.0001$ )

AMOVA conducted on three populations of the Western Cape Province that showed different feeding and breeding behaviors (namely: those feeding on the terminals of healthy trees, the top trunk of dead trees and the bottom trunk of dead trees) resulted in a low between populations (16\%) and a high within populations (84\%) molecular variation. This was further supported by a Fst of 0.09 and Nm of 4.9 (Table 3). 
Table 3 Hierarchical analysis of molecular variance (AMOVA) of Pissodes sp. exhibiting different feeding and breeding site preference: on the terminals of healthy trees, on the upper trunk of dead trees, and on the lower trunk of dead trees

\begin{tabular}{|c|c|c|c|c|c|}
\hline Source of variation & $\overline{D f}$ & SS & MS & Est. Var. & $\%$ \\
\hline Among populations & 2 & 5.41 & 2.70 & $0.11 *$ & $16 \%$ \\
\hline Within populations & 71 & 40.58 & 0.57 & $0.57 *$ & $84 \%$ \\
\hline Overall Fst & & & & $0.09 *$ & \\
\hline Overall $\mathrm{Nm}$ & & & & 4.90 & \\
\hline
\end{tabular}

*Significant at 0.05 level

\section{Discussion}

In this study we examined the identity and genetic diversity of two invasive Pissodes spp. in the southern hemisphere and population structure of the Pissodes sp. in South Africa. Sequence analysis of both the barcoding and the Jerry-to-Pat region of the COI gene revealed the introduction of only one Pissodes species into South Africa. Our results strongly suggest that the species introduced into South Africa and identified as $P$. nemorensis in 1942 (Webb 1974) is very likely not P. nemorensis. Based on current sampling and available GenBank resources, we are not currently able to ascertain the identity of the Pissodes species present in South Africa. The close grouping with the North American species and apparent sister species status with $P$. strobi strongly suggests a North American origin for this weevil, as well as membership in the P. strobi complex. However, this weevil is clearly distinct from the four described members of the P. strobi complex (P. strobi, $P$. nemorensis, $P$. terminalis and $P$. schwarzi). We, therefore, hypothesize the possible existence of an additional, an unrecognized member of this complex or a hybrid between P. nemorensis and P. strobi that has become invasive in South Africa.

It now appears clear that two distinct Pissodes species, very likely of different continental origins and among the most damaging Pissodes species, have been introduced into the southern hemisphere. Our study confirmed the identity of the species in South America (Chile, Uruguay and Argentina) as the small banded pine weevil (P. castaneus), in agreement with the recent confirmation of the species in Argentina (Pereyra et al., 2015b). This species is of Eurasian origin. We detected only a single haplotype in Chile, Argentina and Uruguay, suggesting a single, relatively recent introduction.

Although the Pissodes sp. in South Africa is phylogenetically closest to P. strobi, this relationship was not congruent with the analysis of morphometric data and the observed breeding and feeding behavior. Adults of $P$. strobi lay their eggs on the upper half of the previous year's terminal shoot and the hatching larvae feed gregariously, moving downwards (Belyea \& Sullivan, 1956; Langor et al., 1992). However, the weevil in South Africa often prefers the main trunk of dead or dying Pinus trees and rarely seen feeding and breeding on the terminal leaders (authors' observation). This observed feeding and breeding behavior of the Pissodes sp. in South Africa is more similar to that of $P$. nemorensis in its native range (Atkinson et al., 1988). Pissodes nemorensis shows two types of feeding behaviors in its native range in North America (Ollieu, 1971; Overgaard $\&$ Nachod, 1971). In the first case, it attacks terminal leaders of young healthy trees. In the second case, and 
most commonly, the weevil attacks the main trunk and roots of declining or recently dead trees. Pissodes castaneus has similar plasticity in resource utilization. It attacks pine nursery seedlings, young trees growing on marginal soils and mature plantations stressed by biotic and abiotic factors (Gomez \& Hartel, 2010). Similarly, results from our analysis using morphometric data grouped the Pissodes sp. in South Africa closer to $P$. nemorensis and P. schwarzi than to P. strobi, although still a distinct group.

Cross breeding experiments conducted under laboratory condition have confirmed that some members of the P. strobi complex can interbreed to produce viable offspring (Godwin \& Odell, 1967; Smith \& Takenouchi, 1969). Indications of natural hybridization and mitochondrial introgression between $P$. strobi and P. nemorensis were also reported from their native range (Boyce et al., 1994; Williams \& Langor, 2002). This suggests the possibility that the species in South Africa may be a hybrid, possibly of $P$. strobi and $P$. nemorensis which could explain why the South African Pissodes sp. is phylogenetically closer to P. strobi based on mitochondrial sequence data, but closer to P. nemorensis behaviorally, ecologically and morphologically. Alternatively, it could represent an unrecognized species, probably from North America, though this seems unlikely given considerable study on Pissodes in this region (Langor \& Sperling, 1995; Langor \& Sperling, 1997; Williams \& Langor, 2002).

The possible misidentification of the Pissodes sp. in South Africa is not unique among invasive pest insects. For example, the eucalyptus leaf weevil (formerly known as Gonipterus scutellatus) introduced into Africa, North and South America, Europe and New Zealand, was for many decades considered to be one species (Mapondera et al., 2012). However, recent molecular studies revealed that there are eight cryptic species within the G. scutellatus complex, with G. platensis introduced to New Zealand, North and South America and western Europe, G. pulverulentus to South America and an undescribed species introduced to Africa and southern Europe. Failure to recognize cryptic species may lead to additional damage and implementation of inappropriate regulatory and management programs. Our ability to identify cryptic and invasive species has significantly increased with the development of molecular approaches such as barcoding techniques.

We found 10 haplotypes of Pissodes present along a 578 bp COI sequence segment from 241 individuals from 9 localities in South Africa. This is less than, though comparable to, the 36 haplotypes of $P$. strobi in its native range in North America (826 bp segment of 130 individuals from 11 localities) (Laffin et al., 2004) and 21 haplotypes of $P$. yunnanensis in its native range in China (761 bp segment of 60 individuals from 7 localities) (Zhang et al., 2007). The 0.2 - 1.4\% sequence divergence found among the 10 South African haplotypes falls within the range of the sequence divergence for the above-mentioned studies of Pissodes in its native range (0.001 - $2.1 \%$ for $P$. yunnanensis and 0.12 - 2.54\% for P. strobi; (Laffin et al., 2004; Zhang et al., 2007). Similarly, the nucleotide diversity (Pi) in South Africa (0.002 to 0.006) is comparable to that of $P$. yunnanensis (0.00088 to 0.0033) (Zhang et al., 2007). This considerable amount of mitochondrial genetic diversity for an exotic insect is likely to have resulted either from a single introduction of a large number of individuals, or from multiple introductions over time, both of which occur with some regularity in invasive organisms (Garnas et al., 2016; Nadel et al., 2010). 
A moderate level of genetic differentiation was detected among populations of the Pissodes sp. in different provinces of South Africa. The shared haplotypes between provinces in South Africa and the moderate level of genetic isolation by geographic distance could be the result of historically unregulated plant and wood material movement within the country and natural spread of the weevil. With the natural and human-mediated dispersal of the weevil, it is likely to experience migration and gene flow between populations, even though Pinus plantations in the country are spatially disjunct. A similar pattern of haplotype sharing between populations of an exotic fungus gnat, Bradysia difformitis was reported in four different South African forestry nurseries. Movement of pine nursery plants and bark medium were suspected as possible pathways of movement of the fungus gnat among nurseries (Hurley et al., 2010). The pattern in these invasive populations is, however, in contrast to studies on Pissodes species in their native ranges that have shown population genetic structure based on geographic location (Glaubitz, 2001; Laffin et al., 2004; Zhang et al., 2007). There was no evidence supporting genetic differentiation among terminal leader and bole-feeding individuals in the Western Cape.

The identity of the Pissodes sp. in South America remained unconfirmed for many years (Abgrall et al., 1999; Anon, 1970; O'Brien, 1989). Zaleski et al. (2013) and Marques et al. (2011) mentioned that the Pissodes sp. in Brazil is $P$. castaneus. Recent CABI report stated that P. castaneus is absent from Argentina and Uruguay, but present in Brazil and Chile (CABI, 2014). However, a very recent study supported with mitochondrial and nuclear sequence data reported the Pissodes species in Argentina as P. castaneus (Pereyra et al., 2015b). Our study confirmed the presence of the European species, P. castaneus, in South America (Argentina, Chile and Uruguay). Zaleski et al. (2013) reported considerable genetic diversity of $P$. castaneus based on a study conducted on 19 populations across its introduced range in Brazil using PCR-AFLP data. This substantial amount of diversity suggested the establishment from multiple introduction events as P. castaneus was only detected in Brazil in 2001 (Zaleski et al., 2013). However, our analysis of sequences of the COI gene on three populations from Argentina, Chile and Uruguay (one population from each country) has shown the spread of only a single haplotype throughout these countries, suggesting possible establishment from a limited introduction from single origin. This invasive haplotype matches a haplotype from France and is in complete agreement with Pereyra et al. (2015a) which showed matching of an Argentine haplotype with the one from France. A previous study suggested Uruguay and Argentina as possible sources of the P. castaneus in Brazil (Abgrall et al., 1999), but the link between these populations remains to be studied.

Based on the current trend on the spread of invasive insect pests of forestry trees (Brockerhoff et al., 2006a; Tobin, 2015) further introductions of Pissodes spp. could occur into South Africa and South America, and to other Pinus growing countries. Strict adherence to regulations on the movement of wood products, such as the International Standard for Phytosanitory Measures No. 15 (ISPM15) (Haack et al., 2014) should assist in decreasing the rate of spread of these insects, although it is unlikely to completely stop such movement (Brockerhoff et al., 2006b). Though most Pissodes spp. are pests of secondary importance in their native ranges, there are some species, including $P$. strobi, that cause significant primary damage to conifer plantations. The threat posed by these weevils increases substantially when considering the known association of some species with tree diseases such as Leptographium procerum, Fusarium circinatum (=Fusarium moniliforme var. subglutinans), Cronaritium flaccidum and several species of Ophiostoma, and their possible role in transmitting 
these diseases (Blakeslee et al., 1981; Coutinho et al., 2007; Jankowiak \& Bilański, 2013; Lewis \& Alexander, 1986). The establishment of the pitch canker fungus, F. circinatum, in nurseries, established and mature Pinus plantations in South Africa (Coutinho et al., 2007; Mitchell et al., 2011; Wingfield et al., 2008) and its presence in South America (Wingfield et al., 2008), undoubtedly increases the importance of these two invasive Pissodes spp. It is therefore worthwhile investigating the role of Pissodes sp. and P. castaneus in the transmission and spread of tree pathogenic fungi such as F. circinatum.

The present study demonstrated the importance of using a combination of morphological and molecular approaches to ascertain species identity of invasive pest species. Results of this study will have implications on quarantine, research and management of these two invasive Pissodes species. Countries in the southern hemisphere which were already infested by either of the two invasive Pissodes species should avoid further introductions of the same species or other Pissodes species in order to prevent introduction of multiple genotypes of same species or cryptic forms which may then complicate pest problem via admixture and hybridization. Growers in the northern hemisphere (native range of Pissodes) should be aware of the possibilities for back introductions of P. castaneus and Pissodes sp. from their invasive range, which may lead to complex pest problems via admixture. The presence of a single haplotype of $P$. castaneus in its introduced range in South America and lack of strong genetic structure among geographic populations of the Pissodes sp. in South Africa suggests the possibility of using the same or similar management approaches across the invasive ranges of each of these Pissodes species. Further studies are required in order to determine whether the Pissodes sp. in South Africa is an unrecognized member of the $P$. strobi complex or a hybrid/introgression between $P$. strobi and $P$. nemorensis using a combination of classical taxonomic approaches, breeding (hybridization) experiments and molecular approaches.

\section{References}

Abgrall JF, Villèn González V, Porcile JF (1999) Estudios de investigación sobre gorgojo de los pinos (I parte). Peligro a la vista. Chil For 24:9-13

Alfaro R (1994) The white pine weevil in British Columbia: biology and damage. In: Alfaro RI, Kiss G, Fraser RG (eds) The white pine weevil: biology, damage and management. British Columbia Ministry of Forests and Lands, Pacific Forestry Centre,Victoria, pp 7-22

Alfaro RI ,Ying CC (1990) Levels of Sitka spruce weevil, Pissodes strobi (Peck), damage among Sitka spruce provenances and families near Sayward, British Columbia. The Can Entomol 122:607-615

Anon (1970) Banded pine weevil (Pissodes notatus F.). Insects not known to occur in the USA. Coop Econ Insect Rep 8:65-66

Atkinson TH, Foltz JL, Connor MD (1988) Bionomics of Pissodes nemorensis Germar (Coleoptera: Curculionidae) in northern Florida. Ann Entomol Soc Am 81:255-261

Aukema JE, Leung B, Kovacs K, Chivers C, Britton KO, Englin J, Frankel SJ, Haight RG, Holmes TP, Liebhold AM (2011) Economic impacts of non-native forest insects in the continental United States. PLoS One 6: e24587 
Bandelt H-J, Forster P, Röhl A (1999) Median-joining networks for inferring intraspecific phylogenies. Mol Biol Evol 16:37-48

Belyea RM, Sullivan CR (1956) The white pine weevil: a review of current knowledge. For Chron 32:58-67

Blakeslee GM, Foltz JL, Oak SW (1981) The deodar weevil, a vector and wounding agent associated with pitch canker of slash pine. Phytopathology 71(8):861

Boissin E, Hurley BP, Wingfield MJ, Vasaitis R, Stenlid J, Davis C, Groot P de, Ahumada R, Carnegie A, Goldarazena A, Klasmer P, Wermelinger B, Slippers B (2012) Retracing the routes of introduction of invasive species: the case of the Sirex noctilio woodwasp. Mol Ecol 21:5728-5744

Boyce TA, Zwick ME, Aquadro CF (1994) Mitochondrial DNA in the bark weevils: Phylogeny and evolution in the Pissodes strobi species group (Coleoptera: Curculionidae). Mol Biol Evol 11:183-194

Brockerhoff EG, Bain J, Kimberley M, Knížek M (2006a) Interception frequency of exotic bark and ambrosia beetles (Coleoptera: Scolytinae) and relationship with establishment in New Zealand and worldwide. Can J For Res 36:289-298

Brockerhoff EG, Liebhold AM, Jactel H (2006b) The ecology of forest insect invasions and advances in their management. Can J For Res 36:263-268

CABI (2014) Data sheet. Pissodes castaneous. Invasive species compendium web, http://www.cabi.org/isc/datasheet/41485, Accessed 13 April 2016

Cognato AI, Hoebeke ER, Kajimura H, Smith SM (2015) History of the exotic ambrosia beetles Euwallacea interjectus and Euwallacea validus (Coleoptera: Curculionidae: Xyleborini) in the United States. J Econ Entomol 108: 1129-1135

Coutinho TA, Steenkamp ET, Mongwaketsi K, Wilmot M, Wingfield MJ (2007) First outbreak of pitch canker in a South African pine plantation. Australas Plant Pathol 36:256-261

Craighead FC (1950) Insect enemies of eastern forests. Washington DC, US Department of Agriculture

Darriba D, Taboada GL, Doallo R, Posada D (2012) jModelTest 2: more models, new heuristics and parallel computing. Nat Methods 9:772-772

Day KR, Nordlander G, Kenis M, Halldorson G (2004) General biology and life cycles of bark weevils. In: Lieutier F, Day KR, Battisti A, Grégoire JC, Evans HF (eds) Bark and wood boring insects in living trees in Europe, a synthesis. Springer, New York, USA, pp 331-349

EPPO (1999) Reporting service: Pissodes nemorensis present in Asia vol No. 4 edn. EPPO, Paris, France

Felsenstein J (1985) Confidence limits on phylogenies: an approach using the bootstrap. Evolution 39:783-791

Fontaine MS, Foltz JL, Nation JL (1983) Reproductive anatomy and seasonal development of the deodar weevil, Pissodes nemorensis (Coleoptera: Curculionidae), in north Florida. Environ Entomol 12:687691

Garnas JR, Hurley BP, Slippers B, Wingfield MJ (2012) Biological control of forest plantation pests in an interconnected world requires greater international focus. Int J Pest Manage 58: 211-223

Garnas JR, Auger-Rozenberg M-A, Roques A, Bertelsmeier C, Wingfield MJ, Saccaggi DL, Roy HE, Slippers B (2016) Complex patterns of global spread in invasive insects: Eco-evolutionary and management consequences. Biol Invasions doi :10.1007/s10530-016-1082-9

Glaubitz J (2001) Randomly amplified polymorphic DNA reveals fine-scale genetic structure in Pissodes strobi (Coleoptera: Curculionidae). Can Entomol 133:229-238 
Godwin PA, Odell TM (1967) Experimental hybridization of Pissodes strobi and P. approximatus (Coleoptera: Curculionidae). Ann Entomol Soc Am 60:55-58

Gomez C, Hartel M (2010) El gorgojo de la corteza del pino, Pissodes castaneus. In: Villacide JM, Corley JC (eds.) Serie Técnica: Manejo integrado de plagas forestales. Laboratorio de Ecología de Insectos, INTA EEA Bariloche, Argentina

Goodwin SB, Drenth A, Fry WE (1992) Cloning and genetic analyses of two highly polymorphic, moderately repetitive nuclear DNAs from Phytophthora infestans. Curr Gen 22:107-115

Guindon S, Dufayard J-F, Lefort V, Anisimova M, Hordijk W, Gascuel O (2010) New algorithms and methods to estimate maximum-likelihood phylogenies: assessing the performance of PhyML 3.0. Syst Biol 59:307-321

Haack RA, Britton KO, Brockerhoff EG, Cavey JF, Garrett LJ, Kimberley M, Lowenstein F, Nuding A, Olson LJ, Turner J, Vasilaky KN (2014) Effectiveness of the International Phytosanitary Standard ISPM No. 15 on reducing wood borer infestation rates in wood packaging material entering the United States. PLoS One 9(5):1-15

Hall T (1999) BioEdit: a user-friendly biological sequence alignment editor and analysis program for Windows 95/98/NT. Nucleic Acids Symp Ser 45:95-98

Hurley BP, Slippers B, Wingfield BD, Govender P, Smith JE, Wingfield MJ (2010) Genetic diversity of Bradysia difformis (Sciaridae: Diptera) populations reflects movement of an invasive insect between forestry nurseries. Biol Invasions 12:729-733

Iede ET, Filho WR, Zaleski SRM, Marques FdeA, Caldato N (2007) Monitoramento e controle de Pissodes castaneus em Pinus spp. Circular Têcnica, Colombo

Jankowiak R, Bilański P (2013) Association of the pine-infesting Pissodes species with ophiostomatoid fungi in Poland. Eur J For Res 132:523-534

Katoh K, Standley DM (2013) MAFFT multiple sequence alignment software version 7: improvements in performance and usability. Mol Biol Evol 30:772-780

Keller RP, Geist J, Jeschke JM, Kühn I (2011) Invasive species in Europe: ecology, status, and policy. Environ Sci Eur 23:1-17

Laffin RD, Langor DW, Sperling FAH (2004) Population structure and gene flow in the white pine weevil, Pissodes strobi (Coleoptera: Curculionidae). Ann Entomol Soc Am 97:949-956

Langor DW, Drouin JA, Wong HR (1992) The lodgepole terminal weevil in the Prairie provinces. Forest Management Note 55:7, Forestry Canada, Northern Forestry Centre, Edmonton, Alberta

Langor DW, Sperling FAH (1997) Mitochondrial DNA sequence divergence in weevils of the Pissodes strobi species complex (Coleoptera: Curculionidae). Insect Mol Biol 6:255-265

Langor DW, Sperling FAH (1995) Mitochondrial DNA variation and identification of bark weevils in the Pissodes strobi species group in western Canada (Coleoptera: Curculionidae). Can Entomol 127:895911

Lewis KJ, Alexander SA (1986) Insects associated with the transmission of Verticicladiella procera. Can J For Res 16:1330-1333

Librado P, Rozas J (2009) DnaSP v5: a software for comprehensive analysis of DNA polymorphism data. Bioinformatics 25:1451-1452 
Mapondera TS, Burgess T, Matsuki M, Oberprieler RG (2012) Identification and molecular phylogenetics of the cryptic species of the Gonipterus scutellatus complex (Coleoptera: Curculionidae: Gonipterini). Aust J Entomol 51:177-188

Marques FA, Zaleski SRM, Lazzari S, Frensch G, Senhorini GA, Maia BHLNS, Tröger A, Francke W, Ieded ET, Mori K (2011) Identification of (1R, 2S)-grandisal and (1R, 2S)-grandisol in Pissodes castaneus male-produced volatiles: evidence of a sex pheromone. J Braz Chem Soc 22:1050-1055

Mattson WJ (1998) Exotic insects in North American forests: ecological systems forever altered. In: Britton KO (eds) Exotic pests of eastern forests. Proceedings of a conference, April 8-10, 1997, Nashville, Tennessee, USA, pp 187-193

McCullough DG, Work TT, Cavey JF, Liebhold AM, Marshall D (2006) Interceptions of nonindigenous plant pests at US ports of entry and border crossings over a 17-year period. Biol Invasions 8:611-630

Mitchell RG, Steenkamp ET, Coutinho TA, Wingfield MJ (2011) The pitch canker fungus, Fusarium circinatum: implications for South African forestry. Southern Forests: J For Sci 73:1-13

Nadel RL, Slippers B, Scholes MC, Lawson SA, Noack AE, Wilcken CF, Bouvet JP, Wingfield MJ (2010) DNA bar-coding reveals source and patterns of Thaumastocoris peregrinus invasions in South Africa and South America. Biol Invasions 12:1067-1077

O'Brien CW (1989) Revision of the weevil genus Pissodes in Mexico with notes on Neotropical Pissodini (Coleoptera, Curculionidae). Trans Am Entomol Soc 415-432

Ollieu MM (1971) Damage to southern pines in Texas by Pissodes nemorensis. J Econ Entomol 64:1456-1459

Overgaard NA, Nachod LH (1971) Deodar weevil causes pine mortality in Louisiana. J Econ Entomol 64:13291330

Panzavolta T, Tiberi R (2010) Observations on the life cycle of Pissodes castaneus in central Italy. Bull Insectol 63:45-50

Peakall R, Smouse PE (2012) GenAlEx 6.5: genetic analysis in Excel. Population genetic software for teaching and research-an update. Bioinformatics 28:2537-2539

Pereyra VA, Gomez CA, La Manna L, Roux G, Lanteri AA, Vallejos NC, Marvaldi AE (2015) Introduction and establishment of Pissodes castaneus (Coleoptera: Curculionidae) in the Andean Patagonia of Argentina. J Econ Entomol: tov304

Phillips TW, Teale SA, Lanier GN (1987) Biosystematics of Pissodes Germar (Coleoptera: Curculionidae): seasonality, morphology, and synonymy of P. approximatus Hopkins and P. nemorensis Germar. Can Entomol 119:465-480

Phillips TW, West JR, Foltz JL, Silverstein RM, Lanier GN (1984) Aggregation pheromone of the deodar weevil, Pissodes nemorensis (Coleoptera: Curculionidae): isolation and activity of grandisol and grandisal. J Chem Ecol 10:1417-1423

Simon C, Frati F, Beckenbach A, Crespi B, Liu H, Flook P (1994) Evolution, weighting, and phylogenetic utility of mitochondrial gene sequences and a compilation of conserved polymerase chain reaction primers. Ann Entomol Soc Am 87:651-701

Smith SG, Sugden BA (1969) Host trees and breeding sites of native North American Pissodes bark weevils, with a note on synonymy. Ann Entomol Soc Am 62:146-148 
Smith SG, Takenouchi Y (1969) Chromosomal polymorphism in Pissodes weevils: Further on incompatibility in P. terminals. Can J Genet Cytol 11:761-782

StatSoft (2013) Statistica 12. Tulsa, OK: Stat Soft Inc

Steve P, Shaw F (1958) Cooperative economic insect report. Plant Pest Control Division, Agricultural Research Service, Department of Ariculture, USA

Swofford D (2000) PAUP* 4.0: Phylogenetic Analysis Using Parsimony. Sinauer Associates, Sunderland, Massachusetts

Tamura K, Peterson D, Peterson N, Stecher G, Nei M, Kumar S (2011) MEGA5: molecular evolutionary genetics analysis using maximum likelihood, evolutionary distance, and maximum parsimony methods. Mol Biol Evol 28:2731-2739

Tobin PC (2015) Ecological consequences of pathogen and insect invasions. Current Forestry Report 1:25-32

Webb D van V (1974) Forest and timber entomology in the Republic of South Africa. Entomology Memor No. 34: 1-21, Department of Agricultural Techinical Services, Republic South Africa

Williams DJM, Langor DW (2002) Morphometric study of the Pissodes strobi complex (Coleoptera: Curculionidae). Can Entomol 134:447-466

Wingfield MJ, Hammerbacher A, Ganley RJ, Steenkamp ET, Gordon RT, Wingfield BD, Coutinho TA (2008) Pitch canker caused by Fusarium circinatum - a growing threat to pine plantations and forests worldwide. Australas Plant Pathol 37:319-334

Zaleski SRM, Lazzari S, Lazzarotto CM, Panzavolta T, Iede ET ,Marques FdeA (2013) Genetic structure of populations of Pissodes castaneus (De Geer)(Coleoptera, Curculionidae) using amplified fragment length polymorphism. Rev Bras Entomol 57:405-410

Zhang H, Langor DW, Ye H, Li Z, Laffin RD (2007) Genetic divergence among populations of Pissodes yunnanensis (Coleoptera: Curculionidae) in southwestern China. Can Entomol 139:308-318

Zhang R (2007) Species, distribution and host plants of genus Pissodes (Coleoptera: Curculionidae) and its potential invasive threat. Scientia Silvae Sinicae 43:38-43 


\section{Supplementary material}

ESM 1 Sampling areas, GPS coordinates and number of specimens used for genetic and morphometric studies of the Pissodes sp. in South Africa

\begin{tabular}{|c|c|c|c|c|c|c|c|}
\hline \multirow[t]{2}{*}{ Province } & \multirow{2}{*}{$\begin{array}{l}\text { Plantation } \\
\text { (population) }\end{array}$} & \multirow[t]{2}{*}{ Site } & \multirow[t]{2}{*}{ Latitude } & \multirow[t]{2}{*}{ Longitude } & \multicolumn{3}{|c|}{ Number of insects } \\
\hline & & & & & $\mathrm{n} 1$ & $\mathrm{n} 2$ & n3 \\
\hline \multirow{9}{*}{ Western Cape } & \multirow{3}{*}{ Braken Hill } & S14 & S 34 $00.785^{\prime}$ & ${\mathrm{E} 23^{\circ} 06.868^{\prime}}^{\circ}$ & 10 & 2 & 3 \\
\hline & & $\mathrm{S} 30$ & S $34^{\circ} 01.246^{\prime}$ & E $23^{\circ} 07.271^{\prime}$ & 10 & 4 & 4 \\
\hline & & $\mathrm{S} 23$ & S $34^{\circ} 01.621^{\prime}$ & E $23^{\circ} 06.749^{\prime}$ & 10 & 3 & 4 \\
\hline & \multirow{3}{*}{ Ruigtevlei } & F16 & S 33 59.644' & E $22^{\circ} 53.261^{\prime}$ & 10 & 7 & 5 \\
\hline & & G14 & S $33^{\circ} 59.358^{\prime}$ & E $22^{\circ} 52.412^{\prime}$ & 10 & 2 & 2 \\
\hline & & $\mathrm{G} 20$ & S $33^{\circ} 59.542^{\prime}$ & E $22^{\circ} 53.006^{\prime}$ & 10 & 4 & 4 \\
\hline & \multirow{3}{*}{ Bergplaas } & K14 & ${\mathrm{S} 33^{\circ} 51.889^{\prime}}^{\prime}$ & E $22^{\circ} 41.017^{\prime}$ & 2 & 0 & 0 \\
\hline & & E12 & S $33^{\circ} 55.656^{\prime}$ & E $22^{\circ} 40.748^{\prime}$ & 8 & 4 & 8 \\
\hline & & $\mathrm{A} 2$ & S $33^{\circ} 55.849^{\prime}$ & E $22^{\circ} 46.094^{\prime}$ & 4 & 2 & 1 \\
\hline \multirow{9}{*}{ Mpumalanga } & \multirow{3}{*}{ Helvetia } & $\mathrm{C} 43 \mathrm{a}$ & $\mathrm{S} 25^{\circ} 30.000^{\prime}$ & E $30^{\circ} 22.026^{\prime}$ & 8 & 0 & 0 \\
\hline & & E31 & $\mathrm{S} 25^{\circ} 33.011^{\prime}$ & E $30^{\circ} 18.040^{\prime}$ & 10 & 1 & 1 \\
\hline & & $\mathrm{C} 32$ & $\mathrm{~S} 25^{\circ} 32.002^{\prime}$ & E $30^{\circ} 23.017^{\prime}$ & 10 & 3 & 3 \\
\hline & \multirow{3}{*}{ Torbumlea } & T13A & S $26^{\circ} 11.986^{\prime}$ & E $30^{\circ} 35.118^{\prime}$ & 10 & 1 & 2 \\
\hline & & $\mathrm{T} 7 \mathrm{~A}$ & S $26^{\circ} 12.209^{\prime}$ & E $30^{\circ} 35.054^{\prime}$ & 9 & 2 & 2 \\
\hline & & $\mathrm{T} 17$ & S $26^{\circ} 10.174^{\prime}$ & E $30^{\circ} 32.156^{\prime}$ & 10 & 4 & 4 \\
\hline & \multirow{3}{*}{ Rooihoogte } & N56 & S $26^{\circ} 38.031^{\prime}$ & E $30^{\circ} 20.046^{\prime}$ & 10 & 2 & 2 \\
\hline & & $\mathrm{N} 12 \mathrm{~A}$ & S $26^{\circ} 00.004^{\prime}$ & E $30^{\circ} 17.031^{\prime}$ & 9 & 2 & 3 \\
\hline & & V32 & S $26^{\circ} 02.028^{\prime}$ & E $30^{\circ} 15.050^{\prime}$ & 10 & 0 & 2 \\
\hline \multirow{9}{*}{ KwaZulu-Natal } & \multirow{3}{*}{ Shafton } & C5B & $\mathrm{S} 29^{\circ} 23.128^{\prime}$ & E $30^{\circ} 14.489^{\prime}$ & 6 & 1 & 1 \\
\hline & & $7 B-1$ & $\mathrm{~S} 29^{\circ} 23.363^{\prime}$ & E $30^{\circ} 14.304^{\prime}$ & 10 & 2 & 1 \\
\hline & & $7 B-2$ & $\mathrm{~S} 29^{\circ} 23.363^{\prime}$ & E $30^{\circ} 14.304^{\prime}$ & 10 & 3 & 3 \\
\hline & \multirow{3}{*}{ De Rust } & A32 & S 28 $97.816^{\prime}$ & E $30^{\circ} 60.200^{\prime}$ & 10 & 4 & 4 \\
\hline & & B49B & $\mathrm{S} 29^{\circ} 39.144^{\prime}$ & E $30^{\circ} 63.659^{\prime}$ & 10 & 2 & 2 \\
\hline & & C17A & S $28^{\circ} 99.958^{\prime}$ & E $30^{\circ} 63.664^{\prime}$ & 9 & 7 & 5 \\
\hline & \multirow{3}{*}{ Underberg } & M24A & S $29^{\circ} 83.235^{\prime}$ & E $29^{\circ} 69.000^{\prime}$ & 8 & 4 & 3 \\
\hline & & D2 & S $29^{\circ} 65.661^{\prime}$ & E $29^{\circ} 611.69^{\prime}$ & 10 & 0 & 0 \\
\hline & & $\mathrm{B} 16$ & $\mathrm{~S} 29^{\circ} 67.353^{\prime}$ & E $29^{\circ} 71.086^{\prime}$ & 8 & 2 & 3 \\
\hline
\end{tabular}

\footnotetext{
${ }^{\mathrm{n} 1}$ number specimens from which the Jerry-to-Pat region of COI gene was sequenced

${ }^{\mathrm{n} 2}$ number of female insects used for morphometric study

${ }^{\mathrm{n} 3}$ number of male insects used for morphometric study
} 
EMS 2 Species, number, collection locality and country information of the non-South African specimens of which the Jerry-to-Pat and barcoding region of COI gene was sequenced

\begin{tabular}{lllcc}
\hline Pissodes & Locality & Country & \multicolumn{2}{c}{ No. insects sequenced } \\
\cline { 4 - 5 } species & & Canada & 2 & 2 \\
\hline P.nemorensis & Angus, Ontario & USA & 2 & 2 \\
P.nemorensis & Syracuse, New York & USA & 2 & 3 \\
P. nemorensis & Gainesville, Florida & USA & 5 & 2 \\
Undetermined & Pennsylvania & Spain & 3 & 2 \\
Undetermined & Begonte, Lugo & Czech Republic & 2 & 2 \\
Undetermined & Brno, Southern Moravia & Czech Republic & 2 & 2 \\
Undetermined & Bzenec, Southern Moravia & 9 & 9 \\
Undetermined & Futalelfu, Los Lagos & Chile & 1 & 6 \\
Undetermined & - & Uruguay & 2 & 3 \\
Undetermined & Esquel, Chubut & Argentina & 1 & 0 \\
P. castaneus & Toulon & France & 1 & 0 \\
P. castaneus & Framura & Italy & 1 & 0 \\
P. castaneus & Bratislava & Slovakia & & \\
\hline & & & 2 & 2 \\
\hline
\end{tabular}


ESM 3 Estimates of net sequence divergence between different Pissodes spp. based on sequences of the Jerry-to-Pat region of the COI gene

\begin{tabular}{|c|c|c|c|c|c|c|c|c|c|c|c|c|c|c|c|c|c|c|c|}
\hline Sequences of Pissodes spp. & 1 & 2 & 3 & 4 & 5 & 6 & 7 & 8 & 9 & 10 & 11 & 12 & 13 & 14 & 15 & 16 & 17 & 18 & 19 \\
\hline 1. Pissodes sp., South Africa & 0.000 & & & & & & & & & & & & & & & & & & \\
\hline 2. P. strobi, across Canada (GenBank) & 0.032 & & & & & & & & & & & & & & & & & & \\
\hline 3. P. strobi, East Canada (GenBank) & 0.031 & 0.000 & & & & & & & & & & & & & & & & & \\
\hline 4. P. strobi, Central Canada (GenBank) & 0.031 & 0.002 & 0.001 & & & & & & & & & & & & & & & & \\
\hline 5. P. strobi, West Canada (GenBank) & 0.035 & 0.000 & 0.001 & 0.005 & & & & & & & & & & & & & & & \\
\hline 6. P. nemorensis (GenBank) & 0.067 & 0.080 & 0.079 & 0.076 & 0.083 & & & & & & & & & & & & & & \\
\hline 7. P. nemorensis, USA and Canada & 0.064 & 0.078 & 0.076 & 0.076 & 0.081 & 0.004 & & & & & & & & & & & & & \\
\hline 8. P. terminalis (GenBank) & 0.070 & 0.077 & 0.075 & 0.076 & 0.080 & 0.008 & 0.004 & & & & & & & & & & & & \\
\hline 9. P. schwarzi (GenBank) & 0.082 & 0.086 & 0.086 & 0.086 & 0.088 & 0.075 & 0.071 & 0.080 & & & & & & & & & & & \\
\hline 10. P. castaneus, Argentina & 0.125 & 0.119 & 0.119 & 0.126 & 0.118 & 0.133 & 0.128 & 0.128 & 0.105 & & & & & & & & & & \\
\hline 11. P. castaneus, Uruguay & 0.125 & 0.119 & 0.119 & 0.126 & 0.118 & 0.133 & 0.128 & 0.128 & 0.105 & 0.000 & & & & & & & & & \\
\hline 12. P. castaneus, Chile & 0.125 & 0.119 & 0.119 & 0.126 & 0.118 & 0.133 & 0.128 & 0.128 & 0.105 & 0.000 & 0.000 & & & & & & & & \\
\hline 13. P. castaneus, Spain & 0.125 & 0.122 & 0.122 & 0.129 & 0.121 & 0.137 & 0.132 & 0.132 & 0.103 & 0.004 & 0.004 & 0.004 & & & & & & & \\
\hline 14. P. pini, Czech Republic & 0.119 & 0.120 & 0.120 & 0.127 & 0.120 & 0.121 & 0.112 & 0.112 & 0.105 & 0.027 & 0.027 & 0.027 & 0.025 & & & & & & \\
\hline 15. P. castaneus, Czech Republic & 0.116 & 0.117 & 0.115 & 0.121 & 0.117 & 0.114 & 0.105 & 0.105 & 0.109 & 0.112 & 0.112 & 0.112 & 0.111 & 0.105 & & & & & \\
\hline 16. P. castaneus, France & 0.128 & 0.124 & 0.123 & 0.131 & 0.123 & 0.139 & 0.129 & 0.128 & 0.110 & 0.004 & 0.004 & 0.004 & 0.008 & 0.027 & 0.112 & & & & \\
\hline 17. P. castaneus Italy & 0.124 & 0.124 & 0.123 & 0.131 & 0.123 & 0.123 & 0.114 & 0.114 & 0.110 & 0.029 & 0.029 & 0.029 & 0.029 & 0.002 & 0.107 & 0.029 & & & \\
\hline 18. P. castaneus, Slovenia & 0.119 & 0.119 & 0.118 & 0.126 & 0.118 & 0.118 & 0.110 & 0.109 & 0.105 & 0.025 & 0.025 & 0.025 & 0.025 & 0.002 & 0.102 & 0.025 & 0.004 & & \\
\hline 19. P. affinis (GenBank) & 0.159 & 0.163 & 0.162 & 0.165 & 0.164 & 0.156 & 0.146 & 0.146 & 0.135 & 0.134 & 0.134 & 0.134 & 0.133 & 0.125 & 0.110 & 0.129 & 0.124 & 0.124 & 0.000 \\
\hline
\end{tabular}


ESM 4 Estimates of net sequence divergence between different Pissodes spp. based on sequences of the barcoding region of the COI gene

\begin{tabular}{|c|c|c|c|c|c|c|c|c|c|c|c|c|c|c|c|}
\hline Sequences of Pissodes spp. & 1 & 2 & 3 & 4 & 5 & 6 & 7 & 8 & 9 & 10 & 11 & 12 & 13 & 14 & 15 \\
\hline 1. Pissodes sp., South Africa & 0.000 & & & & & & & & & & & & & & \\
\hline 2. P. strobi (BOLD System) & 0.037 & & & & & & & & & & & & & & \\
\hline 3. P. nemorensis, USA and Canada & 0.074 & 0.081 & & & & & & & & & & & & & \\
\hline 4. $P$. castaneus, Argentina & 0.117 & 0.120 & 0.101 & & & & & & & & & & & & \\
\hline 5. P. castaneus, Uruguay & 0.117 & 0.120 & 0.101 & 0.000 & & & & & & & & & & & \\
\hline 6. P. castaneus, Chile & 0.117 & 0.120 & 0.101 & 0.000 & & & & & & & & & & & \\
\hline 7. P. castaneus, Spain & 0.117 & 0.128 & 0.101 & 0.010 & 0.010 & 0.010 & & & & & & & & & \\
\hline 8. P. validirostris (BOLD System) & 0.114 & 0.102 & 0.109 & 0.108 & 0.108 & 0.108 & 0.115 & & & & & & & & \\
\hline 9. P. pini (BOLD System) & 0.138 & 0.139 & 0.126 & 0.133 & 0.133 & 0.133 & 0.132 & 0.124 & & & & & & & \\
\hline 10. P. piniphilus (BOLD System) & 0.186 & 0.193 & 0.181 & 0.150 & 0.149 & 0.150 & 0.149 & 0.147 & 0.160 & & & & & & \\
\hline 11. P. harcyniae (BOLD System) & 0.188 & 0.196 & 0.184 & 0.174 & 0.174 & 0.174 & 0.180 & 0.167 & 0.169 & 0.115 & & & & & \\
\hline 12. P. punctatus (BOLD System) & 0.185 & 0.190 & 0.180 & 0.166 & 0.166 & 0.166 & 0.172 & 0.156 & 0.170 & 0.078 & 0.120 & & & & \\
\hline 13. P. pini, Czech Republic & 0.132 & 0.135 & 0.126 & 0.135 & 0.136 & 0.135 & 0.135 & 0.122 & 0.007 & 0.161 & 0.166 & 0.180 & & & \\
\hline 14. P. castaneus, Czech Republic & 0.121 & 0.130 & 0.105 & 0.027 & 0.027 & 0.027 & 0.024 & 0.126 & 0.135 & 0.152 & 0.179 & 0.179 & 0.138 & & \\
\hline 15. Curculio slicivorus (GenBank) & 0.190 & 0.200 & 0.197 & 0.212 & 0.211 & 0.212 & 0.212 & 0.213 & 0.232 & 0.196 & 0.209 & 0.188 & 0.228 & 0.000 & \\
\hline
\end{tabular}


EMS 5 Mean \pm SE and range of morphometric characters of adults of the Pissodes sp. in South Africa

\begin{tabular}{|c|c|c|c|}
\hline $\begin{array}{l}\text { Character } \\
\text { code }\end{array}$ & Character & $\begin{array}{l}\text { Female } \\
(n=68)\end{array}$ & $\begin{array}{l}\text { Male } \\
(n=72)\end{array}$ \\
\hline MW & Width of snout at apex & $\begin{array}{l}0.49 \pm 0.0051 \\
(0.38-0.58)\end{array}$ & $\begin{array}{l}0.49 \pm 0.0043 \\
(0.36-0.56)\end{array}$ \\
\hline NP & Width of snout at narrowest point & $\begin{array}{l}0.33 \pm 0.0038 \\
(0.21-0.37)\end{array}$ & $\begin{array}{l}0.37 \pm 0.0033 \\
(0.27-0.42)\end{array}$ \\
\hline AW & Width of snout at anterior insertion & $\begin{array}{l}0.38 \pm 0.0042 \\
(0.29-0.44)\end{array}$ & $\begin{array}{l}0.40 \pm 0.0036 \\
(0.29-0.45)\end{array}$ \\
\hline SL & Length of snout between apex and eye margin at mid-height & $\begin{array}{l}2.39 \pm 0.0349 \\
(1.56-3.03)\end{array}$ & $\begin{array}{l}2.06 \pm 0.0226 \\
(1.41-2.43)\end{array}$ \\
\hline MA & Length of snout between antennal insertion and apex & $\begin{array}{l}1.22 \pm 0.0205 \\
(0.77-1.60)\end{array}$ & $\begin{array}{l}0.95 \pm 0.0113 \\
(0.63-1.17)\end{array}$ \\
\hline SD & Depth of snout at antennal insertion & $\begin{array}{l}0.33 \pm 0.0037 \\
(0.24-0.42)\end{array}$ & $\begin{array}{l}0.33 \pm 0.0033 \\
(0.24-0.41)\end{array}$ \\
\hline PL & Length of pronotum on midline & $\begin{array}{l}2.01 \pm 0.0261 \\
(1.46-2.54)\end{array}$ & $\begin{array}{l}1.98 \pm 0.221 \\
(1.35-2.35)\end{array}$ \\
\hline PW & Width of pronotum at widest point & $\begin{array}{l}2.37 \pm 0.0309 \\
(1.68-2.87)\end{array}$ & $\begin{array}{l}2.33 \pm 0.0288 \\
(1.48-2.87)\end{array}$ \\
\hline EL & Length of elytra along midline & $\begin{array}{l}4.69 \pm 0.0628 \\
(3.04-5.63)\end{array}$ & $\begin{array}{l}4.48 \pm 0.0498 \\
(3.08-5.25)\end{array}$ \\
\hline EB & Width of elytra at base & $\begin{array}{l}2.69 \pm 0.0342 \\
(1.86-3.23)\end{array}$ & $\begin{array}{l}2.63 \pm 0.0290 \\
(1.70-3.09)\end{array}$ \\
\hline PD & Depth of pronotum along posterior margin & $\begin{array}{l}1.83 \pm 0.0240 \\
(1.30-2.17)\end{array}$ & $\begin{array}{l}1.78 \pm 0.0204 \\
(1.14-2.08)\end{array}$ \\
\hline FL & Length of fore femur & $\begin{array}{l}1.98 \pm 0.0253 \\
(1.38-2.35)\end{array}$ & $\begin{array}{l}1.96 \pm 0.0221 \\
(1.31-2.26)\end{array}$ \\
\hline FW & Width of fore femur at widest point & $\begin{array}{l}0.60 \pm 0.0076 \\
(0.43-0.72)\end{array}$ & $\begin{array}{l}0,59 \pm 0,0064 \\
(0.38-0.68)\end{array}$ \\
\hline SN & Snout narrowness, defined as the ratio of SL/NP & $\begin{array}{l}7.29 \pm 0.0694 \\
(5.62-8.74)\end{array}$ & $\begin{array}{l}5.57 \pm 0.0407 \\
(4.44-6.72)\end{array}$ \\
\hline SA & Snout apex proportion, defined as the ratio of MA/SL & $\begin{array}{l}0.51 \pm 0.0023 \\
(0.44-0.55)\end{array}$ & $\begin{array}{l}0.46 \pm 0.0021 \\
(0.43-0.50)\end{array}$ \\
\hline SS & Relative snout length, defined as the ratio of SL/EL & $\begin{array}{l}0.51 \pm 0.0022 \\
(0.45-0.55)\end{array}$ & $\begin{array}{l}0.46 \pm 0.0027 \\
(0.41-0.55)\end{array}$ \\
\hline
\end{tabular}

